Western University Scholarship@Western

Psychology

Psychology

6-1-2001

\title{
Spirituality in late adulthood
}

Lisa M. Heintz

Imants Barušs

King's University College, baruss@uwo.ca

Follow this and additional works at: https://ir.lib.uwo.ca/kingspsychologypub

Part of the Psychology Commons

Citation of this paper:

Heintz, Lisa M. and Barušs, Imants, "Spirituality in late adulthood" (2001). Psychology. 7.

https://ir.lib.uwo.ca/kingspsychologypub/7 
Spirituality in Late Adulthood 1

\section{Spirituality in Late Adulthood ${ }^{1}$}

Lisa M. Heintz and Imants Barušs

King's College, University of Western Ontario

(C) 2001 Lisa M. Heintz and Imants Barušs

${ }^{1}$ This research was done as an undergraduate project by the first author that was supervised by the second author. Address correspondence to Imants Barušs, King's College, 266 Epworth Ave., London, Ontario, Canada N6A 2M3. 
Spirituality in Late Adulthood 2

\begin{abstract}
Summary.-MacDonald's Expressions of Spirituality Inventory was used to examine spirituality in late adulthood using a sample of 30 people ( 22 women, 8 men) with a mean age of 72.6 years. While average scores are higher on scales measuring spiritual and religious beliefs and practices for the sample than a standardization group of undergraduate students with a mean age of 21.0 years, they are lower on scales measuring paranormal beliefs. Low death anxiety is correlated only with Existential Well-Being and age. And while some religious behaviors such as frequent religious practice, prayer, and church attendance are correlated with some of the dimensions of spirituality, many of the scores on the Expressions of Spirituality Inventory scales are independent of self-reported religious behaviors.
\end{abstract}

In a study with 534 undergraduate students (398 women, 136 men), MacDonald developed a factoranalytic model of spirituality based on 11 representative measures of spirituality selected from a pool of 73 paper and pencil measures relevant to the construct of spirituality. In a second study with 938 undergraduate students ( 675 women, 263 men) with a mean age of 21.0 years ( $S D=4.3$ years), he used factor and reliability analyses to refine the model and develop a 98-item Expressions of Spirituality Inventory with good psychometric properties (MacDonald, LeClair, Holland, Alter, \& Friedman, 1995; MacDonald, 1997, 2000). Through this process MacDonald has identified five dimensions of spirituality that are measured by the scales of the Expressions of Spirituality Inventory. The Cognitive Orientation Towards Spirituality is a measure of spiritual beliefs and their personal relevance, the Experiential/Phenomenological Dimension of Spirituality is a measure of the occurrence of spiritual experiences, Existential Well-Being is a measure of "spirituality as expressed through a sense of meaning and purpose for existence, and a perception of self as ... competent and able to cope with the difficulties of life and limitations of human experience" (MacDonald, 2000, p. 187), Paranormal Beliefs is a measure of belief in paranormal phenomena, and Religiousness is a measure of Judeo-Christian religious beliefs and practices. Spirituality is a broader construct than religiosity so that religiosity is at least partially included in spirituality. Four of the five dimensions of spirituality were found to be largely independent of the five dimensions of personality. The exception was Existential Well-Being "which appears to reflect the positive pole of Neuroticism" and has been shown to be "inversely related to depression and general psychopathology" (MacDonald, 2000, p. 192).

Three issues have frequently arisen in discussions concerning spirituality among elderly persons. The first is the contention that religious beliefs and behaviors increase during the adult years; and a second contention is that religious beliefs mitigate a person's fear of death (Spilka, Hood, \& Gorsuch, 1985; Hood, Spilka, Hunsberger, \& Gorsuch, 1996). Third, correspondence between religious beliefs and self-reported religious behaviors is not clear. The purpose of this study was to apply MacDonald's Expressions of Spirituality Inventory to an examination of these three issues concerning spirituality in elderly persons.

\title{
Method
}

People in late adulthood were recruited from senior citizens' drop-in centers, nursing homes and the general public. Each of the participants was given the Expressions of Spirituality Inventory as well as a 10-item questionnaire requesting demographic information and information about religious behaviors and fear of death. Thirty adults ( 22 women, 8 men), in about the same ratio of women to 
Spirituality in Late Adulthood 3

men as in MacDonald's studies, and aged 60 to 90 years, with an average age of 72.6 years $(S D=$ 8.9 years), nine of whom were married and 15 widowed, completed all of the items on the questionnaires.

Measures of religiosity included frequency of religious/spiritual practice which had values of 1 through 5 anchored by never and daily; length of religious/spiritual practice was given in years; church attendance, reading religious material, watching religious programs on television, listening to the radio, and praying were each scored 1 if respondents indicated that they practised them and scored 0 otherwise; and lack of death anxiety was estimated by a number from 0 to 10 on the basis of the location of a check mark on an analogue scale, with "very afraid" at one pole and "not at all afraid" at the other pole, in response to a request for participants to indicate their fear toward death.

TABLE 1

Means and Standard Deviations for MacDonald's Norms and the Present Sample on the Expressions of Spirituality Inventory

\begin{tabular}{|c|c|c|c|c|c|c|c|c|}
\hline \multirow[t]{2}{*}{ Scale } & \multirow[t]{2}{*}{ Dimension } & \multicolumn{2}{|c|}{ MacDonald } & \multicolumn{2}{|c|}{ present study } & \multirow{2}{*}{$\underline{\mathrm{df}}$} & \multirow{2}{*}{$\underline{\mathrm{t}}$} & \multirow[b]{2}{*}{$\mathrm{p}$} \\
\hline & & $\underline{\mathrm{M}}$ & $\underline{\mathrm{SD}}$ & $\underline{\mathrm{M}}$ & $\underline{\mathrm{SD}}$ & & & \\
\hline $\mathrm{COS}$ & $\begin{array}{l}\text { Cognitive Orientation Towards } \\
\text { Spirituality }\end{array}$ & 89.9 & 29.1 & 112.3 & 30.7 & 29 & 4.01 & .001 \\
\hline EPD & $\begin{array}{l}\text { Experiential/Phenomenological } \\
\text { Dimension of Spirituality }\end{array}$ & 33.3 & 12.6 & 37.8 & 13.1 & 29 & 1.86 & $\underline{\mathrm{ns}}$ \\
\hline EWB & Existential Well-Being & 21.9 & 6.2 & 24.0 & 5.6 & 29 & 2.05 & .050 \\
\hline PAR & Paranormal Beliefs & 26.9 & 10.5 & 19.5 & 8.7 & 29 & -4.67 & .001 \\
\hline REL & Religiousness & 41.1 & 14.7 & 52.0 & 14.0 & 29 & 4.29 & .001 \\
\hline
\end{tabular}

Note. $N=938$ for MacDonald and $N=30$ for the present study. MacDonald's norms were treated as constants and two-tailed tests were used for $\underline{t}$ statistics. Descriptions of Expressions of Spirituality Inventory dimensions can be found in MacDonald (2000, pp. 187-188). 
Spirituality in Late Adulthood 4

TABLE 2

Correlations of Expressions of Spirituality Inventory Dimensions with Religious Behaviors and Death Anxiety $(N=30)$

\begin{tabular}{lrrrrr}
\hline \multirow{2}{*}{ Religious Behaviors and Death Anxiety } & \multicolumn{5}{c}{ Dimensions of Spirituality* } \\
\cline { 2 - 7 } & COS & EPD & EWB & PAR & REL \\
\hline Frequency of religious/spiritual practice & .71 & $\mathbf{. 4 0}$ & .26 & -.29 & $\mathbf{. 7 0}$ \\
Length of religious/spiritual practice & $\mathbf{5 9}$ & .17 & -.11 & -.16 & $\mathbf{. 6 4}$ \\
Church attendance & $\mathbf{. 6 4}$ & $\mathbf{. 4 2}$ & .14 & -.28 & $\mathbf{. 6 4}$ \\
Reading religious material & $\mathbf{. 5 9}$ & .25 & -.13 & .02 & $\mathbf{. 6 0}$ \\
Watching religious programs on television & .33 & -.01 & .20 & -.31 & .29 \\
Listening to religious programs on radio & .19 & -.14 & -.14 & -.28 & .08 \\
Praying & $\mathbf{. 6 6}$ & .31 & -.15 & -.21 & $\mathbf{. 7 1}$ \\
\hline Lack of death anxiety & -.11 & -.10 & $\mathbf{. 5 2}$ & -.09 & -.09 \\
\hline
\end{tabular}

Note. Correlations in boldface type are significant at $p<.05$ using two-tailed tests. ${ }^{*}$ The full names of the dimensions of spirituality are given in Table 1.

\section{Results}

The means and standard deviations on all scales are given in Table 1 for the present sample and also for MacDonald's earlier sample. Comparisons between samples yielded significant $t$ ratios for all scales but the Experiential/Phenomenological Dimension of Spirituality.

Table 2 provides Pearson intercorrelations among the scores.

These data support the first contention regarding spirituality in late adulthood, namely, that those in late adulthood are more religious than those who are younger in that participants scored higher on the Cognitive Orientation Towards Spirituality and Religiousness scales than did the undergraduate students in MacDonald's study. Those in late adulthood are not more spiritual with regard to other dimensions of spirituality in the broader sense of spirituality found by MacDonald. It is not known to what extent these results can be attributed to age differences and to what extent to cohort differences. With regard to the second contention, spiritual, religious and paranormal beliefs and experiences are unrelated to self-reported death anxiety. However, there are statistically significant correlations of .52 and .55 , respectively, between scores showing lack of death anxiety with scores 
Spirituality in Late Adulthood 5

on Existential Well-Being and with age. While some religious behaviors such as frequent religious practice, prayer, and church attendance are correlated with some of the dimensions of spirituality, many of the scores on the Expressions of Spirituality Inventory scales are independent of selfreported religious behaviors. Care must be taken in generalizing the results of this study given the small sample size. 
Spirituality in Late Adulthood 6

\section{References}

Hood, R. W., Jr., Spilka, B., Hunsberger, B. \& Gorsuch, R. (1996) The psychology of religion: an empirical approach. (2nd ed.) New York: Guilford.

MacDonald, D. A. (1997). The development of a comprehensive factor analytically derived measure of spirituality and its relationship to psychological functioning. Unpublished doctoral dissertation, University of Windsor, Windsor, Ontario, Canada.

MacDonald, D. A. (2000). Spirituality: description, measurement, and relation to the five factor model of personality. Journal of Personality, 68(1), 153-197.

MacDonald, D. A., LeClair, L, Holland, C. J., Alter, A. \& Friedman, H. L. (1995) A survey of measures of transpersonal constructs. The Journal of Transpersonal Psychology, 27(2), 171235.

Spilka, B., Hood, R. W., Jr., \& Gorsuch, R. L. (1985) The psychology of religion: an empirical approach. Englewood Cliffs, NJ: Prentice-Hall. 